Short Communication

\title{
Congenital rubella syndrome in Haiti
}

\author{
Nancy Golden, ${ }^{1}$ Russell Kempker, ${ }^{1}$ Parul Khator, ${ }^{1}$ \\ Robert Summerlee, ${ }^{1}$ and Arthur Fournier ${ }^{1}$
}

ABSTRACT Objective. To determine if there is an unrecognized problem of congenital rubella syndrome (CRS) in Haiti, a country without a national rubella immunization program.

Methods. During March 2001 and June 2001, screening physicals were conducted on approximately 80 orphans at three orphanages in Haiti that accept disabled children. Children were classified as probable CRS cases based on established clinical criteria. Photo documentation of findings was obtained whenever possible.

Results. Six children met the criteria for probable CRS. Using data from surrounding Caribbean countries and from the United States of America prior to rubella immunization, we estimated that there are between 163 and 440 new cases of CRS per year in Haiti.

Conclusions. CRS exists in Haiti, but its presence is generally unrecognized. A national rubella immunization policy should be considered.

Key words Rubella, congenital rubella syndrome, immunization, cost-benefit analysis, Haiti.

While congenital rubella syndrome (CRS) is virtually extinct in most industrialized countries, it remains a prevalent yet unrecognized disease in many developing nations. In 1941, Gregg reported the association of congenital cataracts with maternal rubella infection (1). While congenital cataracts remain a hallmark diagnostic criteria of CRS, other clinical sequelae of congenital infection have also been identified. Rubella is a generally innocuous infection unless contracted by pregnant women during the first trimester. The rubella virus may then be transmitted transplacentally to the fetus, resulting

\footnotetext{
University of Miami School of Medicine, Department of Family Medicine and Community Health, Miami, Florida, United States of America. Send correspondence to: Arthur M. Fournier; telephone: (305) 243-2847; fax: (305) 243-2888; e-mail: afournie@med.miami.edu
}

in a variety of abnormalities collectively known as congenital rubella syndrome. CRS has been estimated to occur in up to $85 \%$ of infants born to mothers infected during the first 12 weeks of pregnancy, while congenital defects rarely occur after infection beyond the 20th week (2). In general, the earlier in pregnancy the exposure occurs, the greater the risk for CRS. The risk for CRS among infants born to previously immunized women who are reinfected with rubella during pregnancy is minimal $(3,4)$. The severity and site of CRS pathology also depend on gestational age at the time of exposure.

Infants with CRS may continue to shed the rubella virus through urine and respiratory secretions for up to one year. At least $85 \%$ of infants shed the virus at 1 month of age and 1\%-3\% of children continue to do so at 1 year of age. For this reason, CRS infants should be deemed contagious for at least one year and considered an exposure threat to nonimmune pregnant women (2).

In order to determine the presence of CRS clinically, an established list of diagnostic criteria is available. This is depicted in Table 1. Since there is variability as to how long the rubella virus is shed in bodily secretions postpartum, the diagnosis is often made using these clinical criteria rather than laboratory criteria. In addition, laboratory facilities to test for the presence of the virus while the fetus is in utero are often either unavailable or unreliable in developing countries. Using Table 1 , a probable case of CRS is established when a child exhibits either a) two symptoms from category $\mathrm{A}$ or b) one symptom from category $\mathrm{A}$ and one symptom from category B (5). In addition, Table 1 lists "noncategorical" cri- 
TABLE 1. Clinical criteria for congenital rubella syndrome (CRS) used in study of CRS, Haiti, 2001

\begin{tabular}{|c|c|c|c|c|}
\hline Category & Ocular & Central Nervous System & Cardiac & Other \\
\hline A & $\begin{array}{l}\text { Cataracts } \\
\text { Glaucoma } \\
\text { Pigmentary retinopathy }\end{array}$ & Deafness & $\begin{array}{l}\text { Congenital heart disease } \\
\text { (including patent ductus } \\
\text { arteriosus and pulmonary } \\
\text { artery stenosis) }\end{array}$ & $N A^{a}$ \\
\hline B & NA & $\begin{array}{l}\text { Mental retardation } \\
\text { Microcephaly } \\
\text { Meningoencephalitis }\end{array}$ & NA & $\begin{array}{l}\text { Jaundice } \\
\text { Thrombocytopenic purpura } \\
\text { Splenomegaly } \\
\text { Radiolucent bone disease }\end{array}$ \\
\hline Noncategorical & Microphthalmia & Autism & $\begin{array}{l}\text { Ventricular septal defect } \\
\text { Coarctation of the aorta }\end{array}$ & $\begin{array}{l}\text { Hepatitis } \\
\text { Diabetes mellitus } \\
\text { Hepatomegaly } \\
\text { Interstitial pneumonitis } \\
\text { Hyperthyroidism }\end{array}$ \\
\hline
\end{tabular}

a NA $=$ Not applicable.

teria that are associated with CRS but that have less diagnostic significance. Moreover, an accurate diagnosis of CRS can be made when a child exhibits the classic triad of CRS symptoms: congenital cataracts, heart disease, and deafness (6).

In our research results described below, we report six cases of probable CRS among handicapped children in Haiti, identified in the manner just described. Given the emotional, social, and economical costs that CRS inflicts on these children, their families, and society in general, we believe that strategies for rubella immunization in developing countries such as Haiti are worthy of consideration.

Attempts to develop national rubella immunization programs have been increasing worldwide. By 1999, according to the World Health Organization (7), 105 countries had introduced rubella vaccine in their national immunization programs, an increase of 27 countries from 1997. Also by 1999, 79\% of the countries in the Americas had instituted national rubella vaccination programs, the highest percentage of any of the World Health Organization regions. In 1998, 18 of the 19 member countries of the Caribbean Epidemiology Center initiated plans for rubella vaccine mass campaigns, based in part on data from cost-benefit analyses (7). Over the last several years, the use of rubella vaccine in immunization programs for children in the Americas has continued growing. As of early 2002, the vaccine was being used in 38 countries and territories of the Americasthough not yet in Haiti-and was being administered to more than $90 \%$ of one-year-old children (8).

The current immunization program in Haiti is supported by the Pan American Health Organization. Required immunizations are diphtheriapertussis-tetanus (DPT), measles, and oral polio vaccine (OPV). In addition, a BCG vaccine for children has recently been reinstituted. The 2001 immunization coverage rates in Haiti were $49 \%$ for DPT, $53 \%$ for measles, $53 \%$ for OPV, and $49 \%$ for BCG (9).

\section{METHODS}

Medical students and faculty associated with Project Medishare, a charitable organization committed to improving the health of the people of Haiti, have been performing screening examinations for institutionalized orphans in Haiti for the past five years. During our spring and summer trips in 2001, in March and June, respectively, we screened approximately 80 children at three different orphanages in Haiti that accept handicapped children. Our examinations revealed sev- eral children that may represent cases of congenital rubella syndrome. These children were categorized as "probable" cases based on the clinical criteria shown in Table 1. When possible, diagnostic findings were documented using digital photography.

\section{RESULTS}

Six children met the criteria for probable CRS. They ranged in age from 1.1 years to 14 years old. The most common clinical finding, present in four of the six children, was cataracts. Other clinical presentations included deafness, microcephaly, mental retardation, autism, type 1 diabetes mellitus, and symptoms that may be evidence of prior meningoencephalitis, including nuchal rigidity and muscular spasticity. These cases are summarized in Table 2.

\section{DISCUSSION}

Congenital rubella syndrome (CRS) is extremely rare in countries with mandatory rubella immunizations. Unfortunately, these immunizations are not a requirement in many developing countries, including Haiti, which is the poorest nation in the Western Hemisphere. We believe the 
TABLE 2. Summary of congenital rubella syndrome (CRS) cases identified in study of CRS in Haiti, 2001

\begin{tabular}{|c|c|c|c|}
\hline Case & Sex & Age (years) & CRS clinical criteria \\
\hline 1 & Female & 1.5 & $\begin{array}{l}\text { Cataract, left eye } \\
\text { Deafness } \\
\text { Nuchal rigidity } \\
\text { Muscular spasticity }\end{array}$ \\
\hline 2 & Female & 1.1 & $\begin{array}{l}\text { Bilateral cataracts } \\
\text { Microcephaly } \\
\text { Mental retardation }\end{array}$ \\
\hline 3 & Female & 14 & $\begin{array}{l}\text { Deafness } \\
\text { Mental retardation }\end{array}$ \\
\hline 4 & Female & 6 & $\begin{array}{l}\text { Bilateral cataracts } \\
\text { Splenomegaly } \\
\text { Type } 1 \text { diabetes mellitus }\end{array}$ \\
\hline 5 & Female & 1.6 & $\begin{array}{l}\text { Bilateral cataracts } \\
\text { Microcephaly }\end{array}$ \\
\hline 6 & Female & 8 & $\begin{array}{l}\text { Deafness } \\
\text { Mental retardation } \\
\text { Autism }\end{array}$ \\
\hline
\end{tabular}

documentation of the cases that we encountered will serve as evidence that CRS is a health problem needing urgent attention in Haiti. In the past, case reports have been proven to be effective in identifying similar problems (10).

The incidence of CRS must be determined in order to demonstrate that there is a need for a national vaccination program against rubella. No such data currently exist in Haiti. However, a review of rubella seroprevalence studies from the entire Caribbean region shows that $30 \%-50 \%$ of women of childbearing age remain susceptible to rubella infection (11). Furthermore, rough estimates have been made that 20000 or more infants are born with CRS each year in the countries of Latin America and the Caribbean (12). These numbers are not surprising, given the high fertility rates, multiple births, crowding, and young maternal age commonly seen in these nations.

\section{Estimated CRS incidence in Haiti}

Using two different methods, we indirectly estimated the CRS incidence in Haiti. For the first estimation, we used the CRS incidence during prevaccination years in the United States of America and applied it to the following formula:

Incidence of CRS $=($ total population $\times$ birth rate $) \times($ \# new CRS cases annually/100 000 births)

Assuming for Haiti a total population of eight million people and a birth rate of $34 / 1000$ persons (13) as well as a reported rate of 60 new CRS cases /100 000 live births in the United States during prevaccination years (2), the estimated CRS incidence in Haiti is 163 cases per year.

For our second estimation, we applied the average of the prevaccination CRS incidences from rural Jamaica and from rural Trinidad (14) to the above formula. The average was 162/ 100000 births, giving us an incidence of 440 cases per year in Haiti.

Of the two estimates that we computed, we believe the second is a more accurate representation of the true CRS incidence in Haiti. That is because, according to the World Health Organization, the incidence of CRS in countries with no reliable data on the age-specific prevalence of rubella in- fection usually parallels the overall incidence for the region (14). Our two calculated incidences of CRS may both underrepresent the incidence of infection, since the calculations do not take into account the amount of fetal loss due to CRS. When the mother is infected during the first trimester, the risk of spontaneous abortion increases by approximately $50 \%$ (11).

\section{Cost-effectiveness of a vaccination program}

Before any national vaccination program can be established, it must be proven to be cost-effective. To determine the cost of CRS to society, the medical costs of caring for a child with CRS and his or her lost work productivity must both be considered.

The cost of institutionalization of a CRS child in Haiti is highly variable, so we extrapolated from relevant data on developing countries in the Caribbean and Central America (15). In Panama, the annual cost to treat a CRS case was estimated at US\$2 291 in 1989 , and in Jamaica the annual cost was estimated at US\$13 482 in 1997. According to estimates made in 1997, the lifetime cost to treat a CRS case ranged from US\$ 50000 in Barbados to US\$ 63990 in Guyana. In comparison, in the United States in the 1980s, the lifetime cost of caring for a CRS patient was estimated at US\$ 300000 (15).

In addition to medical costs, many of the complications of CRS prevent people afflicted with the disease from entering the workforce, resulting in a significant loss of productivity to society. The Pan American Health Organization (PAHO) reported that the 1999 average life expectancy in Haiti was 54.5 years (13). In addition, the United States Department of State reported that the 1999 gross domestic product (GDP) in Haiti was US\$ 4.115 thousand million and that the labor force included 4.38 million people (16). Dividing the GDP by the size of the labor force gives a GDP per worker of US\$ 940. Estimating an average working lifetime of 40.5 years (assuming a child begins work at 14 years of age), 
Haiti would lose US\$ 38053 in productivity for each person infected with CRS, assuming they would not enter the work force. The previously mentioned costs address only the financial burden to society of CRS children. The emotional costs to parents and society, while immeasurable, are significant and must also be considered.

The cost of rubella vaccine is US\$ 0.15 per dose, based on a 1996 United Nations Children's Fund discounted vaccine price (11). Using this estimate, one can calculate the cost of preventing one case of CRS by using the following equation:

(100 000 live births/CRS incidence per 100000 live births $) \times($ cost of vaccine/dose)

In this equation, the "(100 000 live births/CRS incidence per 100000 live births)" term gives the number of uninfected infants born for each infant born infected with CRS. This value is equivalent to the number of uninfected mothers per infected mother, and thus, the number of mothers that would need to be immunized in order to prevent the birth of one CRS infant. Using the previously calculated average CRS incidence from Jamaica and Trinidad of 162/100 000 live births per year in the above equation, the cost of preventing one case of CRS in Haiti is US\$ 92.60. The above calculations strongly suggest that a national rubella vaccination program in Haiti would be cost-effective.

We have not included non-vaccine costs, since a rubella immunization program could easily be added to existing programs for DPT, polio, BCG, and measles. This would require only a marginal increase in cost, as the personnel and supplies for vaccine administration in Haiti are already funded, with assistance coming from PAHO and other organizations.

There is currently a controversy in the scientific literature concerning rubella immunization and pregnancy. Many fear that a rubella vaccine administered to women shortly before conception or during pregnancy could lead to infection of the fetus. While post-vaccination fetal damage has not been found, women are cautioned against pregnancy for three months after being vaccinated (5).

The rubella vaccine is often administered in combination with the measles and mumps vaccines (MMR vaccine). Case reports of suspected meningitis and encephalitis due to strains of the measles virus in the MMR vaccine have raised questions concerning the value of mass immunizations with this combined vaccine (17). These concerns have recently been resolved by a large study demonstrating the safety of the MMR vaccine and, in particular, the lack of any resulting febrile seizures (18). In addition, allegations that measles vaccine causes autism have been discredited (19). We would argue that the concerns about possible adverse events from vaccination are insignificant in comparison to the costs, disability, and suffering caused by CRS in the absence of vaccination.

\section{Strategies for immunization}

Due to its consistent immunogenicity and lack of side effects, rubella strain RA $27 / 3$ is used by most developed countries, except Japan (2). Japan produces a vaccine that includes the TO336 rubella strain. The standard vaccine dose for both vaccines is 1000 plaque-forming units administered subcutaneously, either alone or in combination with the measles and mumps vaccine. Excellent immune responses are seen with both single and combination vaccines. A single rubella immunization is sufficient for lifetime immunity. It should be noted that there is significant deterioration of the rubella vaccine at room temperature after three months.

Various rubella immunization strategies have been suggested. According to Plotkin (2), the vaccination of infants will lead to the eradication of CRS in 30-40 years, the vaccination of school-age girls to eradication in 10-20 years, and the vaccination of women to immediate eradication if $100 \%$ vaccination is achieved.

In a country of limited resources such as Haiti, it is imperative to develop a cost-effective vaccination program that has an immediate impact, while also preventing future cases of CRS infection. This could be accomplished in Haiti by a combined, selective vaccination of schoolgirls and of postpartum young adult women.

A problem in delivering any strategy in Haiti will be difficulties in infrastructure and access to immunization, particularly in remote rural areas. This problem could be overcome by marrying a CRS immunization program to existing immunization programs for DPT, polio, measles, and BCG. These programs are currently functioning throughout the country and have achieved considerable immunization rates even in remote rural areas (9).

\section{REFERENCES}

1. Gregg NM. Congenital cataract following German measles in the mother. Trans Ophthalmol Soc 1941;3:35-46.

2. Plotkin SA. Rubella vaccine. In: Plotkin SA, Mortimar EA, eds. Vaccines. 2nd ed. London: WB Saunders; 1994. Pp. 235-262.
3. Watson JC, Hadler SC, Dykewicz CA, Reef S, Phillips L. Measles, mumps, and rubellavaccine use and strategies for elimination of measles, rubella, and congenital rubella syndrome and control of mumps: recommendations of the Advisory Committee of
Immunization Practices (ACIP). MMWR Morb Mortal Wkly Rep 1998;47(RR-8): $1-57$.

4. Rubella and congenital rubella syndromeUnited States 1994-1997. MMWR Morb Mortal Wkly Rep 1997;46(16):350-354. 
5. United States of America, Centers for Disease Control and Prevention. Rubella [Internet site]. Available from: http://www.cdc.gov/ nip/publications/pink/rubella.pdf. Accessed 12 August 2001

6. Cutts FT, Robertson SE, Diaz-Ortega JL, Samuel R. Control of rubella and congenital rubella syndrome (CRS) in developing countries, part 1: burden of disease from CRS. Bull World Health Organ 1997;75(1):55-68.

7. World Health Organization, Department of Vaccines and Biologicals. Report of a meeting on preventing congenital rubella syndrome: immunization strategies, surveillance needs. Geneva: WHO; 2000. Available from: URL: http://www.who.int/vaccines-documents. Accessed 5 September 2002. (Document $\mathrm{WHO} / \mathrm{V} \& \mathrm{~B} / 00.10)$

8. Castillo-Solorzano C, de Quadros CA. Control acelerado de la rubéola y prevención del síndrome de rubéola congénita en las Américas. Rev Panam Salud Publica 2002;11(4):273-276.

9. Pan American Health Organization, Division of Vaccines and Immunization. Coverage rates: DPT-3, OPV-3, measles, BCG, Region of the Americas, 2000 and 2001. EPI Newsletter 2002;24(2):7
10. Layde PM, Von Allmen SD, Oakley GP. Congenital hypothyroidism control programs: a cost-benefit analysis. JAMA 1979;241(21): 2290-2292.

11. Robertson SE, Cutts FT, Samuel R, Diaz-Ortega JL. Control of rubella and congenital rubella syndrome (CRS) in developing countries, part 2: vaccination against rubella. Bull World Health Organ 1997;75(1):69-80.

12. St. John MA, Benjamin S. An epidemic of congenital rubella in Barbados. Ann Trop Paediatr 2000;20:231-235.

13. Pan American Health Organization. Haiti: basic country health profiles, summaries 1999 [Internet site]. Available from: http://www. paho.org/english/sha/prflhai.htm. Accessed 5 August 2001.

14. Cutts FT, Vynnycky E. Modeling the incidence of congenital rubella syndrome in developing countries. Int J Epidemiol 1999;28: 1176-1184.

15. Hinman AR, Irons $B$, Lewis $M$, Kandola $K$. Economic analyses of rubella and rubella vaccines: a global review. Bull World Health Organ 2002;80(4):264-270.

16. United States, Department of State. 2001 country reports on economic policy and trade practices [Internet site]. Available from: http://www.state.gov/documents/organization/8205.pdf. Accessed 5 September 2002.

17. Bitnun A, Shannon P, Durward A, Rota PA, Bellini WJ, Graham C, et al. Measles inclusionbody encephalitis caused by the vaccine strain of measles virus. Clin Infect Dis 1999;29: 855-861.

18. Barlow WE, Davis RL, Glasser JW, Rhodes $\mathrm{PH}$, Thompson RS, Mullooly JP, et al. The risk of seizures after receipt of whole-cell pertussis or measles, mumps, and rubella vaccine. $\mathrm{N}$ Engl J Med 2001;345:656-661.

19. Taylor B, Miller E, Farrington CP, Petropoulos MC, Favot-Mayaud I, Li J, et al. Autism and measles, mumps, and rubella vaccine: no epidemiological evidence for a causal association. Lancet 1999;353:2026-2029.

Manuscript received 6 December 2001. Manuscript accepted for publication on 19 June 2002

RESUMEN Objetivos. Determinar si la rubéola congénita es un problema no reconocido en Haití, país que no dispone de un programa nacional de vacunación contra esta enfermedad.

\section{Rubéola congénita en Haití}

Métodos. Entre marzo y junio de 2001 se realizaron exámenes físicos a unos 80 huérfanos de tres orfanatos de Haití que aceptan a niños discapacitados. El diagnóstico de probable rubéola congénita se basó en criterios clínicos establecidos. Siempre que fuera posible se obtuvo documentación fotográfica.

Resultados. Seis niños cumplieron los criterios de probable rubéola congénita. Usando datos de los países vecinos del Caribe y de los Estados Unidos de América anteriores a la vacunación contra la rubéola, se calculó que cada año hay 163 a 440 nuevos casos de rubéola congénita en Haití.

Conclusiones. Sigue existiendo rubéola congénita en Haití, pero generalmente no se reconoce. Se debería considerar la implantación de una política nacional de vacunación contra la rubéola en ese país. 